\title{
Synthesis, Characterization, Crystal Structure and Thermal Behavior of a New Triazolium Salt Along with Docking Studies
}

Seyed Ghorban Hosseini*a, Keyvan Moeini ${ }^{\mathrm{b}}$, Mohammed S. M. Abdelbaky ${ }^{\mathrm{c}}$ and Santiago García-Granda $^{c}$

${ }^{a}$ Department of Chemistry, Malek Ashtar University of Technology, P. O. Box 16765-3454, Tehran, I. R. Iran

${ }^{\mathrm{b}}$ Chemistry Department, Payame Noor University, 19395-4697 Tehran, I. R. Iran

${ }^{c}$ Department of Physical and Analytical Chemistry, University of Oviedo-CINN, 33006 Oviedo, Spain

Corresponding Author: Seyed Ghorban Hosseini.

E-mail: hoseinitol@yahoo.com

\begin{abstract}
A new triazolic compound, 4,5-diamino-3-methyl-4H-1,2,4-triazol-1-ium nitrate $\left(\mathrm{DAMT} \cdot \mathrm{HNO}_{3}\right)$, was synthesized and characterized by elemental analysis, FT-IR, ${ }^{1} \mathrm{H}$ NMR spectroscopy and single-crystal X-ray diffraction along with its thermal behaviors (TGA/DSC). X-ray analysis of the compound revealed a triazolium nitrate salt with a new tautomeric form. Among the different $\mathrm{N}-\mathrm{H} \cdots \mathrm{X}(\mathrm{X}: \mathrm{C}, \mathrm{N}, \mathrm{O})$, the $\mathrm{N}-\mathrm{H} \cdots \mathrm{O}$ ones formed $\mathrm{R}^{2}{ }_{2}(4), \mathrm{R}_{2}{ }_{2}(8), \mathrm{R}_{4}^{4}(18), \mathrm{R}_{4}{ }_{4}(14)$ and $\mathrm{R}^{2}{ }_{1}(4)$ hydrogen bond motifs. The crystal network of DAMT $\cdot \mathrm{HNO}_{3}$ is also stabilized by $\pi-\pi$ stacking interactions between triazole rings. Thermal studies revealed that this compound has a good thermal stability and can released considerable amount of heat in first decomposition step. In continue, thermal properties of this compound are compared with its chloride salt analogue, DAMT $\cdot \mathrm{HCl}$. The
\end{abstract}


thermodynamic stability of DAMT $\cdot \mathrm{HNO}_{3}$ was studied by DFT calculations and compared with DAMT $\cdot \mathrm{HCl}$ and DAMT. The ability of these compounds to interact with DNA molecule was investigated by docking studies.

Keywords: triazole; X-ray crystal structure; docking studies; TGA; DSC; DFT

\section{Introduction}

Triazoles have been widely studied due to their broad spectrum of biological activities, which include anti-bacterial [1], anti-neoplastic [2], anti-tubercular [3], anti-HIV [4], and antiphytopathogenic [5]. Some of them are applied as non-steroidal anti-estrogens [6] and drugs for the therapy of invasive aspergillosis [7]. One of the methods used to link a carbohydrate moiety with a potential compound is via a triazole ring using the well-known "click chemistry" reaction [8]. Triazoles are bioisosteres of amide bonds [9]. This units are in the structure of compounds as receptors for anion recognition [10] and proton exchange membranes [11]. Triazole-based energetic materials are most prominent as nitrogen-rich compounds and they are considered to be the best compromise between high energy, performance and high stability due to nitrogen catenation and aromaticity [12]. Properties such as high nitrogen content together with low sensitivity towards external forces like impact and friction $[13,14]$ make these compounds reliable as safe energetic material.

Herein, the effect of replacing the chloride ion with nitrate on energy component of the 4,5-diamino-3-methyl-4H-1,2,4-triazol-1-ium chloride (DAMT· $\mathrm{HCl}$, Scheme 1), is studied along with the preparation, characterization and crystal structure of the new triazolium nitrate salt, DAMT $\cdot \mathrm{HNO}_{3}$. Also a DFT calculation was run to investigate the thermodynamic stability of the DAMT $\cdot \mathrm{HCl}$ and DAMT $\cdot \mathrm{HNO}_{3}$.

The expected biological properties of the triazoles make this compounds as a good choice for biologically active compound, thus docking calculations were run to investigate 
the possibility of interaction between the DAMT, DAMT $\cdot \mathrm{HNO}_{3}$ and DAMT $\cdot \mathrm{HCl}$ compounds with the B-DNA. The knowledge gained from docking on the B-DNA should be useful for the development of potential probes for DNA structure and new therapeutic reagents for tumors and other diseases [15].

\section{Experimental}

\section{Materials and Instrumentation}

All starting chemicals and solvents were reagent or analytical grade and used as received. The DAMT· $\mathrm{HCl}$ ligand salt was prepared accordingly to the literature [16]. The infrared spectrum of $\mathrm{KBr}$ pellets in the range $400-4000 \mathrm{~cm}^{-1}$ was recorded with a FT-IR 8400Shimadzu spectrometer. ${ }^{1} \mathrm{H}$ NMR spectrum was recorded on a Bruker Advance DPX300 instrument; chemical shifts $\delta$ are given in parts per million, relative to TMS as an internal standard. The carbon, hydrogen and nitrogen contents were determined in a Thermo Finnigan Flash Elemental Analyzer 1112 EA. The melting point was determined with a Barnsted Electrothermal 9200 electrically heated apparatus. TGA/DSC curves were obtained on a STA-780 thermal system with heating rate $10 \mathrm{~K} \mathrm{~min}^{-1}$ in flowing argon atmosphere (flow rate $\left.50 \mathrm{~mL} \mathrm{~min}^{-1}\right)$.

\section{Preparation of DAMT.HNO3}

$0.50 \mathrm{~g}$ (3.34 mmol) of DAMT $\cdot \mathrm{HCl}$ dissolved in $\mathrm{H}_{2} \mathrm{O}-\mathrm{EtOH} 1: 2(15 \mathrm{~mL})$ was added with stirring to a solution of $0.57 \mathrm{~g}(3.34 \mathrm{mmol})$ of $\mathrm{AgNO}_{3}$ in $\mathrm{H}_{2} \mathrm{O}(20 \mathrm{~mL})$. The reaction mixture was refluxed for $6 \mathrm{~h}$ and then filtrated. Colorless crystals suitable for X-ray diffraction were obtained from the solution after standing for a week. Yield: $0.41 \mathrm{~g}, 70 \%$; m. p.: $179{ }^{\circ} \mathrm{C}$. Anal. Calcd for $\mathrm{C}_{3} \mathrm{H}_{8} \mathrm{~N}_{6} \mathrm{O}_{3}$ (176.14): C, 20.46; H, 4.58; N, 47.71. Found: C, 20.66; H, 4.61; N, 48.03\%. IR (KBr disk): $3318 \mathrm{~s}\left(v_{a s} \mathrm{NH}_{2}\right), 3216 \mathrm{~s}\left(v_{s} \mathrm{NH}_{2}\right), 2984 \mathrm{~m}(v \mathrm{C}-\mathrm{H}), 1688 \mathrm{~s}(v \mathrm{C}=\mathrm{N})$, 
$1650 \mathrm{~m}\left(\delta \mathrm{NH}_{2}\right), 1390 \mathrm{~s}\left(v_{4} \mathrm{NO}_{3}\right), 1060 \mathrm{w}\left(v_{2} \mathrm{NO}_{3}\right.$ and/or $\left.v \mathrm{~N}-\mathrm{N}\right) \mathrm{cm}^{-1} .{ }^{1} \mathrm{H} \mathrm{NMR}(250 \mathrm{MHz}$, [D 6 DMSO): $\delta=2.29\left(\mathrm{~s}, 3 \mathrm{H}, \mathrm{CH}_{3}\right), 5.94\left(\mathrm{~s}, 3 \mathrm{H}, \mathrm{NH}_{3}{ }^{+}\right), 8.10\left(\mathrm{~s}, 2 \mathrm{H}, \mathrm{NH}_{2}\right) \mathrm{ppm}$.

\section{Crystal structure determination}

The diffraction data from a selected single crystal was collected at room temperature on an

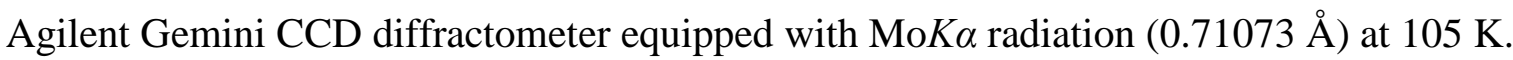
Images were collected at a $55 \mathrm{~mm}$ fixed crystal-detector distance, using the oscillation method, with $1^{\circ}$ oscillation and variable exposure time per image. Using OLEX-II [17] the structures were solved with SHELXS [18]. The refinement was performed using full-matrix least squares on $F^{2}$. All non-H atoms were anisotropically refined. All $\mathrm{H}$ atoms were geometrically placed riding on their parent atoms, with isotropic displacement parameters set at 1.2 times the Ueq of the atoms to which they are attached. The molecular graphics were drawn with Hermes and Mercury [19]. Crystallographic data and details of the data collection and structure refinement, and selected bond lengths and angles are listed in Tables 1 and 2, respectively.

CCDC 1873768 for complex contains the supplementary crystallographic data for this paper. These data can be obtained free of charge via http://www.ccdc.cam.ac.uk/conts/retrieving.html, or from the Cambridge Crystallographic Data Centre, 12 Union Road, Cambridge CB2 1EZ, UK; fax: (+44) 1223-336-033; or e-mail: deposit@ccdc.cam.ac.uk.

\section{Computational details}

All structures were optimized with the Gaussian 09 software [20] and calculated for an isolated molecule using Density Functional Theory (DFT) [21] at the B3LYP/6-31G (d,p) 
[22] level of theory for all compounds. The X-ray structural data of DAMT $\cdot \mathrm{HNO}_{3}$ and DAMT $\cdot \mathrm{HCl}[23]$ was used as input for the theoretical calculations.

\section{Docking details}

The pdb file of 1 bna for the pure B-DNA (only containing free water molecules) used in this research was obtained from the Protein Data Bank (pdb) [24]. The full version of Genetic Optimisation for Ligand Docking (GOLD) 5.5 [25] was used for the docking studies. The Hermes visualizer in the GOLD Suite was used to further prepare the compounds and the receptors for docking. The cif file of the compounds were used for the docking studies. The region of interest was defined on DNA backbone within $10 \AA$ of the O4, DT19 and O2, DT19 atoms on an uracil nucleotide for major and minor grooves, respectively. All free water molecules in the structure of the proteins were deleted before docking. Default values of all other parameters were used and the compounds were submitted to ten genetic algorithm runs using the GOLDScore fitness function. The GOLD docking results are reported in terms of the values of fitness, which grows with better docking interaction of the compounds [26-29]. The results of the docking presented in this work are the best binding results out of ten favorites predicted by GOLD.

\section{Results and Discussion}

Reaction between the triazolium chloride salt (DAMT $\cdot \mathrm{HCl}$ ) and a $\mathrm{EtOH} / \mathrm{H}_{2} \mathrm{O}$ solution of silver(I) nitrate under reflux conditions provides the DAMT $\cdot \mathrm{HNO}_{3}$. The compound is airstable and soluble in $\mathrm{H}_{2} \mathrm{O}$, EtOH and DMSO.

\section{Spectroscopic and thermal studies}

In the IR spectrum of the DAMT $\cdot \mathrm{HNO}_{3}$, the absorption bands at range of $3200-3300 \mathrm{~cm}^{-1}$ are due to the symmetric and asymmetric stretching vibrations of the $\mathrm{RNH}_{2}$ groups on the 
triazolic unit. These peaks are shifted to higher frequencies $\left(46-87 \mathrm{~cm}^{-1}\right)$ respect to the triazolium chloride salt [23] which can be refer to the number and/or strength of the hydrogen bonds in the nitrate salt maybe higher than the chloride ones. Similar shifts were observed for the $\delta\left(\mathrm{NH}_{2}\right)$ vibration $\left(31 \mathrm{~cm}^{-1}\right)$. A band at $1688 \mathrm{~cm}^{-1}$ can be assigned to the vibration of the imine bond, $v(\mathrm{C}=\mathrm{N})^{\text {ar }}$, which is slightly shifted $\left(6 \mathrm{~cm}^{-1}\right)$ to higher frequency in the nitrate salt. Presence of the strong peak at $1390 \mathrm{~cm}^{-1}$, corresponding to the nitrate ion, proves the successful replacing of the chloride on the product.

The ${ }^{1} \mathrm{H}$ NMR spectrum of the title compound, was recorded in DMSO- $d_{6}$ and is consistent with the presence of a protonated DAMT. A singlet peak at the highest magnetic field was assigned to the hydrogen atoms of the methyl group. With decreasing magnetic field two singlet peaks belonging to the two amino groups are observed. Among them, the one at $5.94 \mathrm{ppm}$ with integral of 3 was assigned to the protonated amine group and another at the lowest magnetic field was assigned to the rest amine group.

The TGA/DSC diagrams of DAMT $\cdot \mathrm{HNO}_{3}$ and DAMT $\cdot \mathrm{HCl}$ were presented in Figures 1 and 2, respectively. Based on these curves, the chloride salt has a good thermal stability up to $261{ }^{\circ} \mathrm{C}$ and melts in range of $248-261^{\circ} \mathrm{C}$ by absorbing the $263.75 \mathrm{~J} \mathrm{~g}^{-1}$ heat. Replacing the chloride with nitrate ion, increases the thermodynamic stability of compound up to $280{ }^{\circ} \mathrm{C}$ which is a good parameter for easily and safely casting the compound. During the first decomposition of the nitrate salt $\left(280-309^{\circ} \mathrm{C}\right)$, in which the $80 \%$ of compound converts to the gaseous compounds, considerable amount of heat is released $\left(-1326.57 \mathrm{~J} \mathrm{~g}^{-1}\right)$ which is in contrast with that of the chloride salt. The first decomposition of the chloride salt (291-332 ${ }^{\circ} \mathrm{C}, 73 \%$ ) is endothermic along with the absorption of the $384.69 \mathrm{~J} \mathrm{~g}^{-1}$ heat.

\section{Crystal and molecular structure of DAMT $\cdot \mathrm{HNO}_{3}$}


$\mathrm{X}$-ray analysis of the compound revealed a triazolium salt that crystalized in a triclinic crystal system with $P-1$ space group. A mean plane through the triazolic ring revealed that this ring is planar (r.m.s. value: $0.004 \AA$ for $\mathrm{C} 1$ atom). The $\mathrm{C} 1-\mathrm{N} 5$ bond length, corresponding to the non-protonated amine group is in range of the double bond [30]. This observation allowed us to conclude that a lone pair electrons of the nitrogen atom participates in resonance. Also the planar geometry of the N3 atom can be attributed to the delocalization of its lone pair electrons in the triazole ring. The $\mathrm{N} 4$ atom of amine group is protonated to form a tetrahedral geometry which is naturalized by a nitrate ion. The nitrate ion has a planar structure (r.m.s. value: $0.001 \AA$ for N6 atom) with bond angles in range of the 118.73-120.88 . Comparing the crystal structure of the DAMT $\cdot \mathrm{HNO}_{3}$ with its analogue, $\mathrm{DAMT} \cdot \mathrm{HCl}[23]$ revealed that different nitrogen atoms in these structures is protonated; in DAMT $\cdot \mathrm{HNO}_{3}$ one of the amine groups (N4) is protonated while in DAMT $\cdot \mathrm{HCl}$, a nitrogen atom of the ring (N1) accepts this proton. This observation revealed that the $\mathrm{HDAMT}^{+}$unit of DAMT $\cdot \mathrm{HNO}_{3}($ Scheme 2, c) is a tautomeric isomer with similar unit in the DAMT $\cdot \mathrm{HCl}$ (Scheme 2, b). Also HDAMT ${ }^{+}$exists in two resonance forms including amine and imine (Scheme 2, a and b) [23].

A structural comparison between structure of the DAMT $\cdot \mathrm{HNO}_{3}$ with DAMT [31] revealed that the converting of pure DAMT to its nitrate salt does not effect on planarity of triazole ring (r.m.s. value: $0.004 \AA$ for C2 and N2 atoms of DAMT). Similar to DAMT $\cdot \mathrm{HNO}_{3}$, the $\mathrm{C} 1-\mathrm{N} 5$ bond length in pure DAMT is double bond and is slightly $(0.022$ A) longer than the nitrate salt. All bond lengths and angles in two structures are comparable. Searching the CSD database revealed that there is an analogue of DAMT, 4H-1,2,4-triazole3,4,5-triamine (TTA), containing an amine group instead of methyl [32]. The triazole ring in this molecule is planar (r.m.s. value: $0.002 \AA$ for $\mathrm{C} 1$ ) and two out of ring $\mathrm{C}-\mathrm{N}$ bond lengths 
(1.360(3) and 1.347(3) A) can be consider as double bond. These bonds are slightly longer than that of the DAMT $\cdot \mathrm{HNO}_{3}$ while other bond lengths are comparable.

In the crystal network of the DAMT $\cdot \mathrm{HNO}_{3}$ (Fig. 3), there are intermolecular $\mathrm{N}-\mathrm{H} \cdots \mathrm{C}$ $(2.660 \AA), \mathrm{N}-\mathrm{H} \cdots \mathrm{N}(2.286-2.696 \AA)$ and $\mathrm{N}-\mathrm{H} \cdots \mathrm{O}(2.237-2.659 \AA)$ hydrogen bonds between adjacent units. Among them, the $\mathrm{N}-\mathrm{H} \cdots \mathrm{O}$ hydrogen bonds participate in the formation of $\mathrm{R}^{2}{ }_{2}$ (4) hydrogen bond motif (two acceptors, two donors with degree of four) $[33,34]$ between two nitrate and two triazolium units. Another motifs including $\mathrm{R}_{2}^{4}(8)$ (Fig. 3), $\mathrm{R}_{4}^{4}(18), \mathrm{R}^{2}{ }_{4}(14)$ and $\mathrm{R}^{2}{ }_{1}(4)$ are formed by $\mathrm{N}-\mathrm{H} \cdots \mathrm{O}$ hydrogen bonds. In addition to the hydrogen bonds, the crystal network is stabilized by $\pi-\pi$ stacking interactions between trizolium rings. The centroid-centroid distance and the perpendicular distance between the trizolium rings is 3.640 and $3.276 \AA$, respectively. Thus the slippage of trizolium rings was calculated to be $1.587 \AA$.

For comparing the thermodynamic stability of the crystal networks for DAMT, DAMT $\cdot \mathrm{HCl}, \mathrm{DAMT} \cdot \mathrm{HNO}_{3}$ and TTA, the packing energy of these compounds were calculated by Mercury software [19] using its CSD-materials tool [24, 35]. The packing energy for DAMT, DAMT $\cdot \mathrm{HCl}, \mathrm{DAMT} \cdot \mathrm{HNO}_{3}$ and TTA was calculated to $-97.5,-79.4$, -172.4 and $-121.3 \mathrm{~kJ} / \mathrm{mol}$, respectively. This study revealed that the packing energy of $\mathrm{DAMT} \cdot \mathrm{HNO}_{3}$ is higher than the others thus the nitrate ion more stabilized the crystal network than the chloride one. Also replacing the methyl group of DAMT with amine group (TTA) give rises a stronger intermolecular interactions and more stabilization of the crystal network.

\section{Theoretical studies}

For comparing the structure of the compounds in solid state with an isolated gas-phase one, DFT calculations were performed; the optimized structure is presented in Table 3. Based on 
the X-ray data, the $\mathrm{HDAMT}^{+}$has two tautomeric forms, triazolium (Scheme $2 \mathrm{~b}$ ) and aminium (Scheme $2 \mathrm{c}$ ), thus the nitrate and chloride salts for each tautomeric isomers were optimized to comparing the results (Table 3). Based on the calculated Gibbs free energies for simplest reactions between DAMT with $\mathrm{HNO}_{3}$ and $\mathrm{HCl}$ (Table 4), the aminium salt of chloride $\left(\mathrm{DAMT} \cdot \mathrm{HCl}^{\mathrm{y}}\right)$ and nitrate $\left(\mathrm{DAMT} \cdot \mathrm{HNO}_{3}{ }^{\mathrm{y}}\right)$ is thermodynamically stable than their triazolium one. For nitrate salts, the thermodynamic stability of the aminium salt is -3.83 $\mathrm{kcal} / \mathrm{mol}$ higher than the triazolium salt, similar to the experimental result. Among the four studied reactions, the calculated $\Delta \mathrm{G}^{\circ}(298 \mathrm{~K})$ value for preparation of the aminium salt of nitrate $\left(\mathrm{DAMT} \cdot \mathrm{HNO}_{3}{ }^{\mathrm{y}}\right)$ is negative than the others and thus this compound is thermodynamically stable than the other products. In the optimized structures of the aminium isomers $\left(\mathrm{DAMT} \cdot \mathrm{HCl}^{\mathrm{y}}, \mathrm{DAMT} \cdot \mathrm{HNO}_{3}{ }^{\mathrm{y}}\right.$, Table 3$)$, one proton of the aminium group is attached to the anionic group. A mean plane through the triazolic ring of four optimized structures revealed that this ring is planar (r.m.s. values: $0.001-0.018 \AA$ ) as observed for solid phase structures. In the optimized structure of the compounds, the HOMO and LUMO orbitals are delocalized on the cationic or anionic units (Table 3). When a HOMO or LUMO orbital is placed on one ionic portion, another ionic unit does not have any quota in same frontier orbital.

\section{Docking studies}

For predicting and comparing the biological activities of the DAMT, DAMT $\cdot \mathrm{HNO}_{3}$ and DAMT $\cdot \mathrm{HCl}$, interactions of these compounds with a DNA fragment were studied using the GOLD [25] docking software.

The general features from the GOLD docking prediction (Table 5) show that all studied structures can be considered as biologically active compounds [27-29]. Docking calculations revealed that these compounds can place in the major and minor grooves of the DNA 
molecule which make these compounds a good choice for DNA binding studies. Based on this study, DAMT $\cdot \mathrm{HNO}_{3}$ has higher fitness values than the others. Also docking scores of the DAMT $\cdot \mathrm{HCl}$ is higher than the DAMT, showing that the nitrate and chloride salts of the DAMT can bind to the DNA molecule better than the pure DAMT. The docking results of the interaction between the DAMT, DAMT $\cdot \mathrm{HNO}_{3}$ and DAMT $\cdot \mathrm{HCl}$ with B-DNA (minor groove) are shown in figures 4-6, respectively. As presented at these figures, in addition to the cationic unit, chloride and nitrate ions interact with the DNA molecule.

\section{Conclusion}

In this work, a new triazolic salt, 4,5-diamino-3-methyl-4H-1,2,4-triazol-1-ium nitrate (DAMT $\cdot \mathrm{HNO}_{3}$ ), was synthesized and its spectral (IR, ${ }^{1} \mathrm{H}$ NMR), thermal (TGA/DSC) and structural properties were investigated. The structural analysis revealed an ionic compound containing protonated amine group which is new tautomeric isomer of its chloride salt analogue, DAMT $\cdot \mathrm{HCl}$. Thermal investigation of the DAMT $\cdot \mathrm{HCl}$ and DAMT $\cdot \mathrm{HNO}_{3}$ revealed that replacing the chloride by nitrate ion increases the thermal stability of the compound about $+19{ }^{\circ} \mathrm{C}$ and converts it to a high energetic material. In the crystal structures of the DAMT $\cdot \mathrm{HNO}_{3}$, the nitrate ions along with amine units formed $\mathrm{R}_{2}^{2}(4), \mathrm{R}_{2}^{4}(8), \mathrm{R}_{4}^{4}(18), \mathrm{R}_{4}^{2}(14)$ and $\mathrm{R}^{2}{ }_{1}(4)$ hydrogen bond motifs. In addition to the hydrogen bonds, the crystal network is further stabilized by $\pi-\pi$ stacking interactions between triazole rings. Based on the DFT calculations, the aminium tautomers of the chloride and nitrate salts is thermodynamically stable than the triazolium ones. Docking studies revealed that the studied compounds can interact with the DNA with order of DAMT $\cdot \mathrm{HNO}_{3}>\mathrm{DAMT} \cdot \mathrm{HCl}>\mathrm{DAMT}$, making them promising candidates for anticancer studies.

\section{Acknowledgments}


We acknowledge the financial support from Spanish Ministerio de Economía y

Competitividad (MAT2016-78155-C2-1-R and FPI grant BES-2011-046948 to MSM.A.) and FEDER funding. 


\section{References}

[1] K. Lal, C. P. Kaushik, A. Kumar. Med. Chem. Res. 2015, 24, 3258.

[2] N. A. Al-Masoudi, Y. A. Al-Soud. Tetrahedron Lett. 2002, 43, 4021.

[3] K. Karthik Kumar, S. Prabu Seenivasan, V. Kumar, T. Mohan Das. Carbohyd Res. 2011, 346, 2084.

[4] F. D. C. Da Silva, M. C. B. V. De Souza, I. I. P. Frugulhetti, H. C. Castro, S. L. D. O. Souza, T. M. L. De Souza, D. Q. Rodrigues, A. M. T. Souza, P. A. Abreu, F.

Passamani, C. R. Rodrigues, V. F. Ferreira. Eur. J. Inorg. Chem. 2009, 44, 373.

[5] X. Wang, Z. C. Dai, Y. F. Chen, L. L. Cao, W. Yan, S. K. Li, J. X. Wang, Z. G. Zhang, Y. H. Ye. Eur. J. Med. Chem. 2017, 126, 171.

[6] D. J. Sheehan, C. A. Hitchcock, C. M. Sibley. Clin. Microbiol. Rev. 1999, 12, 40.

[7] S. R. Lockhart, J. P. Frade, K. A. Etienne, M. A. Pfaller, D. J. Diekema, S. A. Balajee. Antimicrob. Agents CH. 2011, 55, 4465.

[8] R. Huisgen, G. Szeimies, L. Möbius. Chem. Ber. 1967, 100, 2494.

[9] M. Taddei, S. Ferrini, L. Giannotti, M. Corsi, F. Manetti, G. Giannini, L. Vesci, F. M. Milazzo, D. Alloatti, M. B. Guglielmi, M. Castorina, M. L. Cervoni, M. Barbarino, R. Foderà, V. Carollo, C. Pisano, S. Armaroli, W. Cabri. J. Med. Chem. 2014, 57, 2258.

[10] V. Haridas, M. B. Bijesh, S. Dhawan, A. Shandilya. Sensor. Actuat. B-Chem. 2017, 245, 903.

[11] M.-K. Ahn, S.-B. Lee, C.-M. Min, Y.-G. Yu, J. Jang, M.-Y. Gim, J.-S. Lee. J. Membrane. Sci. 2017, 523, 480.

[12] V. D. Ghule. Comput. Theor. Chem. 2012, 992, 92.

[13] A. A. Dippold, T. M. Klapötke. Z. Anorg. Allg. Chem. 2011, 637, 1453.

[14] A. A. Dippold, T. M. Klapötke, N. Winter. Eur. J. Inorg. Chem. 2012, 2012, 3474.

[15] N. H. Moghadam, S. Salehzadeh, N. Shahabadi. Nucleos. Nucleot. Nucl. 2017, 36, 553.

[16] R. I. Trust, J. D. Albright, F. M. Lovell, N. A. Perkinson. J. Heterocyclic Chem. 1979, 16, 1393.

[17] O. V. Dolomanov, L. J. Bourhis, R. J. Gildea, J. a. K. Howard, H. Puschmann. J. Appl. Crystallogr. 2009, 42, 339.

[18] G. Sheldrick. Acta Crystallogr. 2008, A64, 112. 
[19] C. F. Macrae, I. J. Bruno, J. A. Chisholm, P. R. Edgington, P. Mccabe, E. Pidcock, L. Rodriguez-Monge, R. Taylor, J. Van De Streek, P. A. Wood. J. Appl. Crystallogr. 2008, 41, 466 .

[20] M. J. Frisch, G. W. Trucks, H. B. Schlegel, G. E. Scuseria, M. A. Robb, J. R. Cheeseman, G. Scalmani, V. Barone, B. Mennucci, G. A. Petersson, H. Nakatsuji, M. Caricato, X. Li, H. P. Hratchian, A. F. Izmaylov, J. Bloino, G. Zheng, J. L.

Sonnenberg, M. Hada, M. Ehara, K. Toyota, R. Fukuda, J. Hasegawa, M. Ishida, T. Nakajima, Y. Honda, O. Kitao, H. Nakai, T. Vreven, J. A. Montgomery Jr., J. E. Peralta, F. Ogliaro, M. J. Bearpark, J. Heyd, E. N. Brothers, K. N. Kudin, V. N. Staroverov, R. Kobayashi, J. Normand, K. Raghavachari, A. P. Rendell, J. C. Burant, S. S. Iyengar, J. Tomasi, M. Cossi, N. Rega, N. J. Millam, M. Klene, J. E. Knox, J. B. Cross, V. Bakken, C. Adamo, J. Jaramillo, R. Gomperts, R. E. Stratmann, O. Yazyev, A. J. Austin, R. Cammi, C. Pomelli, J. W. Ochterski, R. L. Martin, K. Morokuma, V. G. Zakrzewski, G. A. Voth, P. Salvador, J. J. Dannenberg, S. Dapprich, A. D. Daniels, Ö. Farkas, J. B. Foresman, J. V. Ortiz, J. Cioslowski, D. J. Fox, Gaussian 09. 2009, Gaussian, Inc.: Wallingford, CT, USA.

[21] J. P. Perdew. Phys. Rev. 1986, B33, 8822.

[22] R. Ditchfield, W. J. Hehre, J. A. Pople. J. Chem. Phys. 1971, 54, 724.

[23] M. Hakimi, M. Maeder, G. A. Lawrance. J. Coord. Chem. 2011, 64, 105.

[24] A. Gavezzotti. Acc. Chem. Res. 1994, 27, 309.

[25] G. Jones, P. Willett, R. C. Glen, A. R. Leach, R. Taylor. J. Mol. Biol. 1997, 267, 727.

[26] A. A. Adeniyi, P. A. Ajibade. Molecules 2013, 18, 3760.

[27] F. Marandi, K. Moeini, F. Alizadeh, Z. Mardani, C. K. Quah, W.-S. Loh, J. D. Woollins. Inorg. Chim. Acta 2018, 482, 717.

[28] F. Marandi, K. Moeini, F. Alizadeh, Z. Mardani, C. K. Quah, W.-S. Loh. Z. Naturforsch. 2018, 73b, 369.

[29] Z. Mardani, R. Kazemshoar-Duzduzani, K. Moeini, A. Hajabbas-Farshchi, C. Carpenter-Warren, A. M. Z. Slawin, J. D. Woollins. RSC Adv. 2018, 8, 28810.

[30] J. A. Dean, N. A. Lange, Lange's Handbook of Chemistry, McGraw-Hill, pp. 4.37, 1999.

[31] I. S. Konovalova, Y. V. Nelyubina, K. A. Lyssenko, B. V. Paponov, O. V. Shishkin. J. Phys. Chem. 2011, A115, 8550.

[32] C. Darwich, T. M. Klapötke, J. M. Welch, M. Suceska. Propellants, Explos., Pyrotech 2007, 32, 235.

[33] M. Hakimi, Z. Mardani, K. Moeini, F. Mohr, M. A. Fernandes. Polyhedron 2014, 67, 27.

[34] M. Hakimi, K. Moeini, Z. Mardani, F. Mohr. Polyhedron 2014, 70, 92. 
[35] A. Gavezzotti, G. Filippini. J. Phys. Chem. 1994, 98, 4831. 
Table 1. Crystal data and structure refinement for DAMT $\cdot \mathrm{HNO}_{3} \cdot$

\begin{tabular}{|c|c|}
\hline Empirical formula & $\mathrm{C}_{3} \mathrm{H}_{8} \mathrm{~N}_{5} \cdot \mathrm{NO}_{3}$ \\
\hline Formula weight, $\mathrm{g} \mathrm{mol}^{-1}$ & 176.15 \\
\hline Crystal size, $\mathrm{mm}^{3}$ & $0.28 \times 0.18 \times 0.18$ \\
\hline Temperature, $\mathrm{K}$ & 105.0 \\
\hline Crystal system & Triclinic \\
\hline Space group & $P-1$ \\
\hline \multicolumn{2}{|l|}{ Unit cell dimensions } \\
\hline$a, \AA$ & $6.3125(3)$ \\
\hline$b, \AA$ & $6.9572(5)$ \\
\hline$c, \AA$ & $8.5889(4)$ \\
\hline$\alpha,{ }^{\circ}$ & $102.314(5)$ \\
\hline$\beta, \circ$ & $91.436(4)$ \\
\hline$\gamma,^{\circ}$ & $104.051(5)$ \\
\hline Volume, $\AA^{3}$ & $356.32(4)$ \\
\hline$Z$ & 2 \\
\hline Calculated density, $\mathrm{g} \mathrm{cm}^{-3}$ & 1.642 \\
\hline Absorption coefficient, $\mathrm{mm}^{-1}$ & 1.25 \\
\hline$F(000)$ & 184 \\
\hline$\theta$ range for data collection, ${ }^{\circ}$ & $5.3-73.7$ \\
\hline$h, k, l$ ranges & $-7 \leq h \leq 7,-8 \leq k \leq 8,-10 \leq l \leq 10$ \\
\hline Reflections collected / independent / $R_{\text {int }}$ & $5213 / 1444 / 0.025$ \\
\hline Data / restraints / parameters & 1444 / 0 / 109 \\
\hline Goodness-of-fit on $F^{2}$ & 1.07 \\
\hline$R_{1} / w R_{2}(I \geq 2 \sigma(I))$ & $0.0685 / 0.2044$ \\
\hline$R_{1} / w R_{2}$ (all data) & $0.0697 / 0.2056$ \\
\hline Largest diff. peak / hole, e $\AA^{-3}$ & $0.81 /-0.80$ \\
\hline
\end{tabular}

Table 2. Selected bond lengths $(\AA)$ and angles (deg) for the DAMT $\cdot \mathrm{HNO}_{3}$ with estimated standard deviations in parentheses.

\begin{tabular}{|c|c|c|c|}
\hline \multicolumn{2}{|c|}{ Bond lengths $(\AA)$} & \multicolumn{2}{|l|}{ Angles $\left(^{\circ}\right)$} \\
\hline $\mathrm{C}(1)-\mathrm{N}(1)$ & $1.332(4)$ & $\mathrm{C}(1)-\mathrm{N}(3)-\mathrm{C}(2)$ & $108.1(2)$ \\
\hline $\mathrm{C}(1)-\mathrm{N}(5)$ & $1.319(4)$ & $\mathrm{C}(1)-\mathrm{N}(1)-\mathrm{N}(2)$ & $111.5(2)$ \\
\hline $\mathrm{C}(2)-\mathrm{N}(2)$ & $1.302(3)$ & $\mathrm{C}(2)-\mathrm{N}(2)-\mathrm{N}(1)$ & $104.8(2)$ \\
\hline $\mathrm{N}(2)-\mathrm{N}(1)$ & $1.393(4)$ & $\mathrm{N}(3)-\mathrm{C}(1)-\mathrm{N}(1)$ & $105.5(2)$ \\
\hline $\mathrm{N}(3)-\mathrm{C}(1)$ & $1.351(3)$ & $\mathrm{N}(3)-\mathrm{C}(2)-\mathrm{N}(2)$ & $110.2(2)$ \\
\hline $\mathrm{N}(3)-\mathrm{C}(2)$ & $1.383(4)$ & $\mathrm{O}(1)-\mathrm{N}(6)-\mathrm{O}(3)$ & $118.7(2)$ \\
\hline $\mathrm{N}(3)-\mathrm{N}(4)$ & $1.399(3)$ & $\mathrm{O}(2)-\mathrm{N}(6)-\mathrm{O}(1)$ & $120.4(3)$ \\
\hline $\mathrm{O}(1)-\mathrm{N}(6)$ & $1.243(3)$ & $\mathrm{O}(3)-\mathrm{N}(6)-\mathrm{O}(2)$ & $120.9(3)$ \\
\hline $\mathrm{O}(2)-\mathrm{N}(6)$ & $1.239(4)$ & & \\
\hline $\mathrm{O}(3)-\mathrm{N}(6)$ & $1.262(3)$ & & \\
\hline
\end{tabular}


Table 3. The optimized structures, HOMO and LUMO orbitals for triazolium (DAMT $\cdot \mathrm{HCl}^{\mathrm{x}}, \mathrm{DAMT} \cdot \mathrm{HNO}_{3}{ }^{\mathrm{x}}$ ) and aminium (DAMT $\cdot \mathrm{HCl}^{\mathrm{y}}, \mathrm{DAMT} \cdot \mathrm{HNO}_{3}{ }^{\mathrm{y}}$ ) tautomers with the calculated total energy.

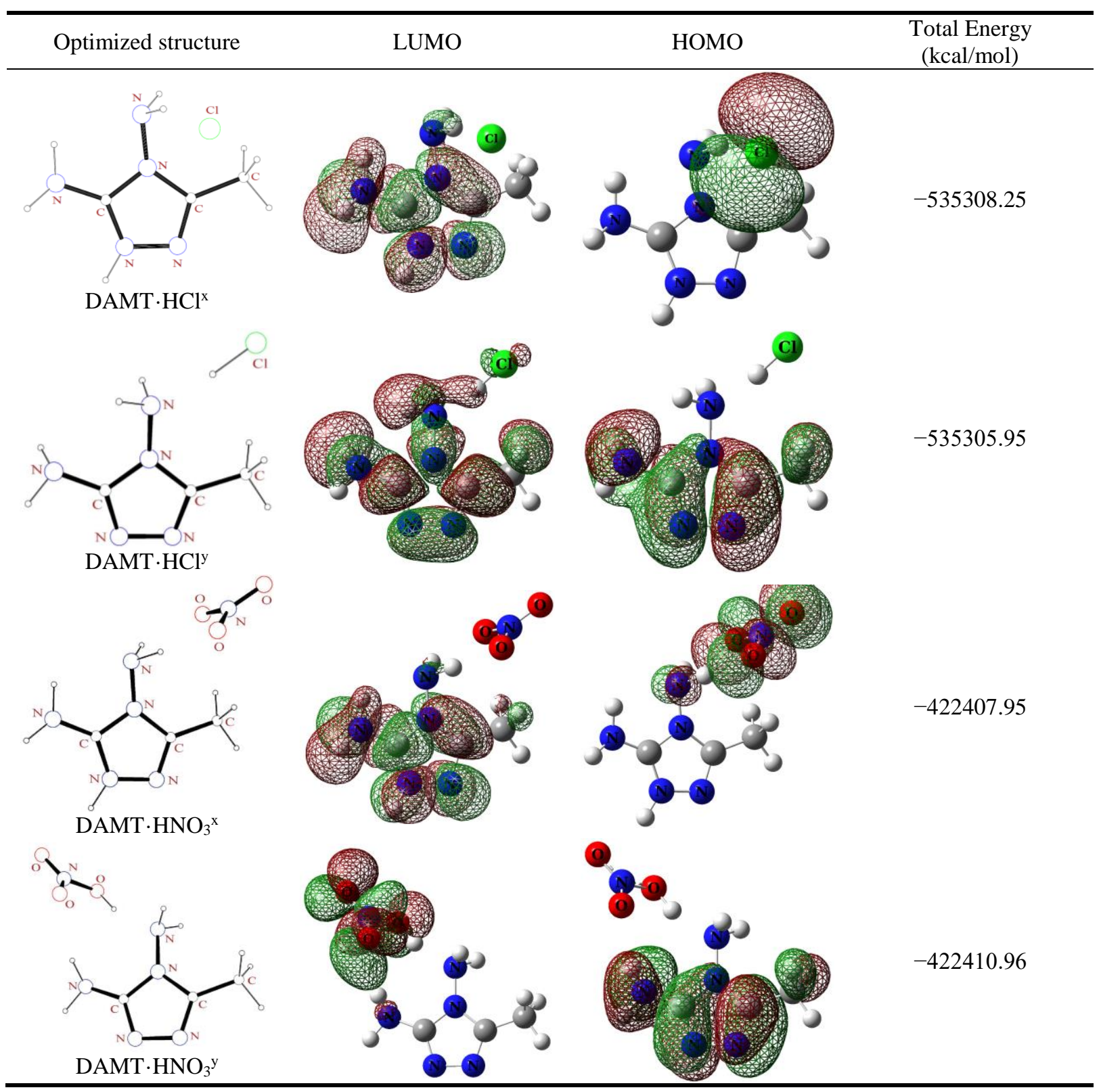

Table 4. Calculated $\Delta \mathrm{G}^{\circ}(298 \mathrm{~K})$ for four studied reactions.

\begin{tabular}{cccccc}
\hline Precursor 1 & & Precursor 2 & & Product & $\begin{array}{c}\Delta \mathrm{G}^{\circ}(298 \mathrm{~K}) \\
\mathrm{Kcal} / \mathrm{mol}\end{array}$ \\
\hline DAMT & + & $\mathrm{HCl}$ & $\rightarrow$ & DAMT $\cdot \mathrm{HCl}^{\mathrm{x}}$ & -4.27 \\
DAMT & + & $\mathrm{HCl}$ & $\rightarrow$ & DAMT $\cdot \mathrm{HCl}^{\mathrm{y}}$ & -5.52 \\
DAMT & + & $\mathrm{HNO}_{3}$ & $\rightarrow$ & DAMT $\cdot \mathrm{HNO}_{3}{ }^{\mathrm{x}}$ & -3.84 \\
DAMT & + & $\mathrm{HNO}_{3}$ & $\rightarrow$ & DAMT $\cdot \mathrm{HNO}_{3}{ }^{\mathrm{y}}$ & -7.67 \\
\hline
\end{tabular}


Table 5. The calculated fitness values for DAMT, DAMT $\cdot \mathrm{HNO}_{3}$ and DAMT $\cdot \mathrm{HCl}$ along with the doxorubicin.

\begin{tabular}{ccc}
\hline & B-DNAs/Maj & B-DNAs/Min \\
\hline DAMT & 16.24 & 29.22 \\
\hline DAMT $\cdot \mathrm{HNO}_{3}$ & 25.50 & 36.18 \\
\hline DAMT $\cdot \mathrm{HCl}$ & 17.70 & 35.21 \\
\hline
\end{tabular}




\section{Scheme and Figure Captions}

Scheme 1. Structure of the 4,5-diamino-3-methyl-4H-1,2,4-triazol-1-ium chloride (DAMT $\cdot \mathrm{HCl})$.

Scheme 2. The different isomeric/tautomeric and resonance forms of the triazolium unit.

Figure 1. TGA/DSC diagram of DAMT $\cdot \mathrm{HCl}$.

Figure 2. The TGA/DSC diagram of DAMT $\cdot \mathrm{HNO}_{3}$.

Figure 3. Packing of DAMT $\cdot \mathrm{HNO}_{3}$, showing the hydrogen bonds.

Figure 4. Docking study results, showing the interaction between DAMT and B-DNA (minor groove).

Figure 5. Docking study results, showing the interaction between DAMT $\cdot \mathrm{HNO}_{3}$ and B-DNA (minor groove).

Figure 6. Docking study results, showing the interaction between DAMT $\cdot \mathrm{HCl}$ and B-DNA (minor groove). 
<smiles>Cc1nnc(Cl)n1N</smiles>

Scheme 1.<smiles>Cc1n[nH]c(=N)n1N</smiles>

(a)<smiles></smiles>

(b)

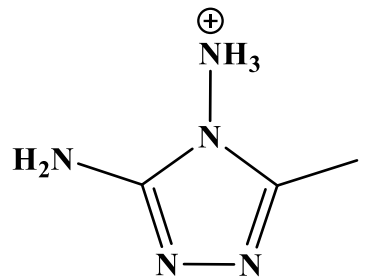

(c)

Scheme 2.

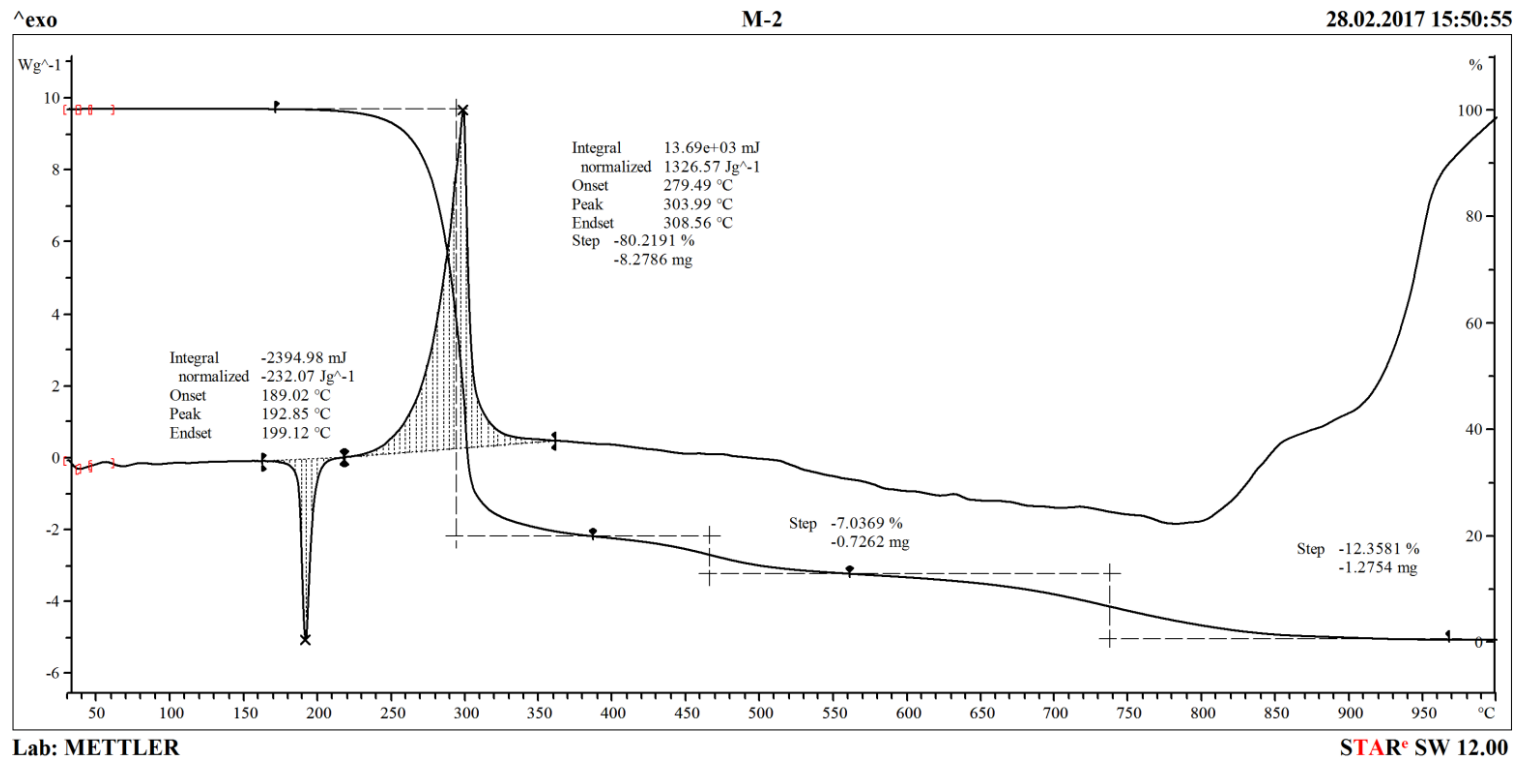

Figure 1. 


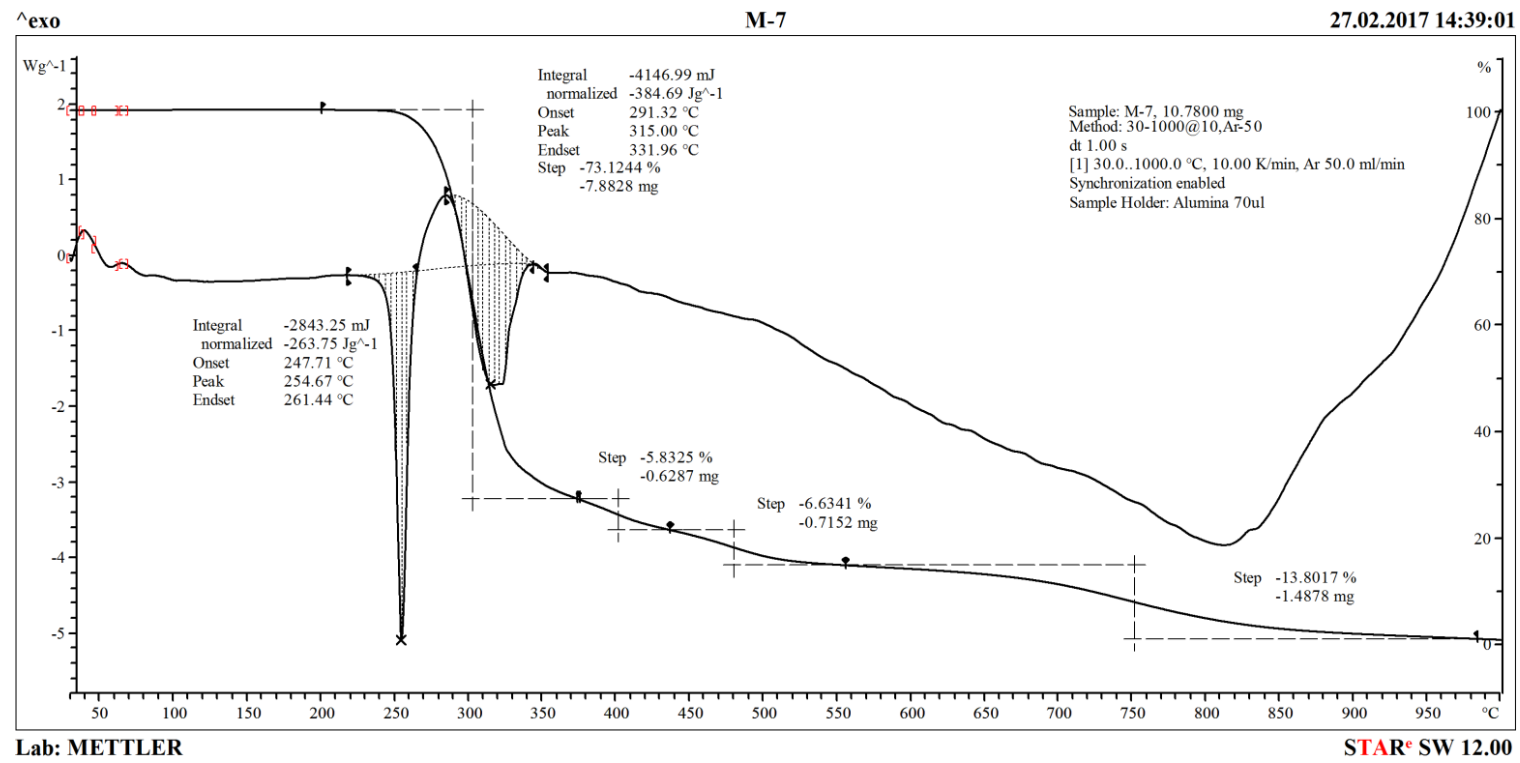

Figure 2.

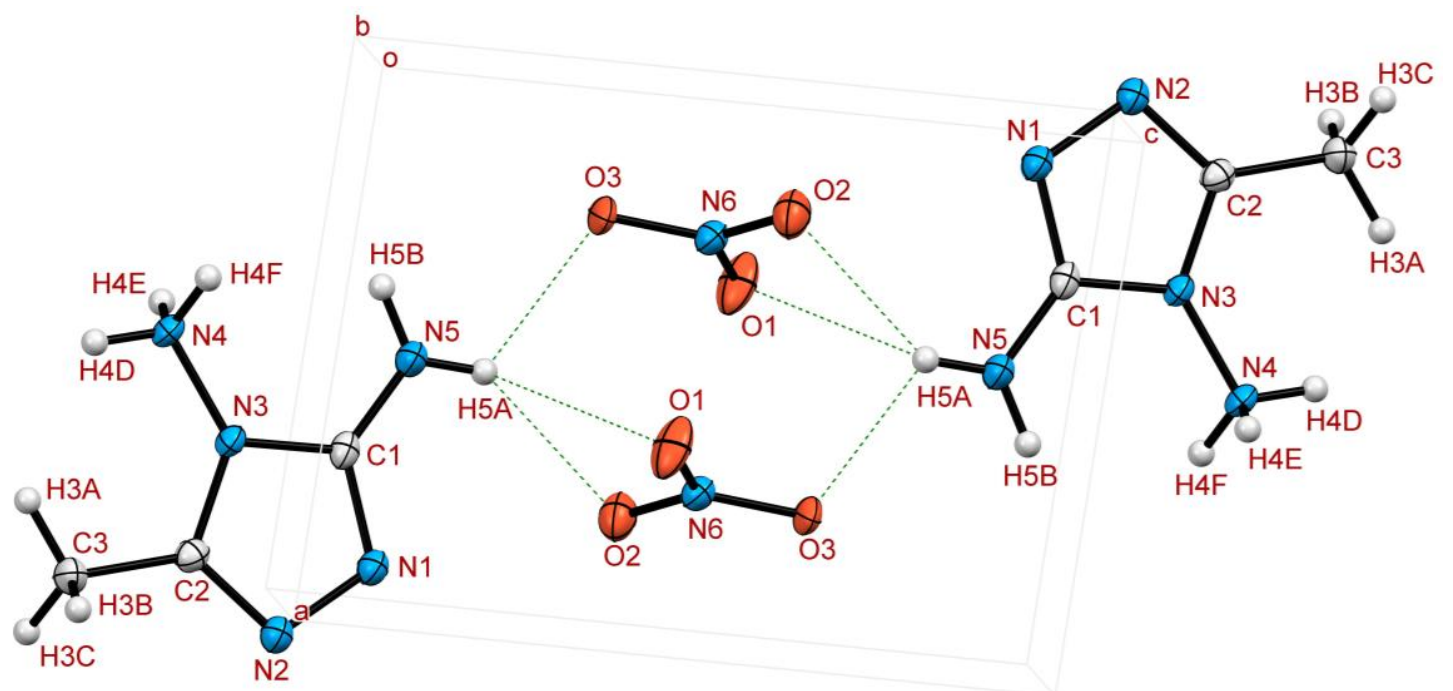

Figure 3. 


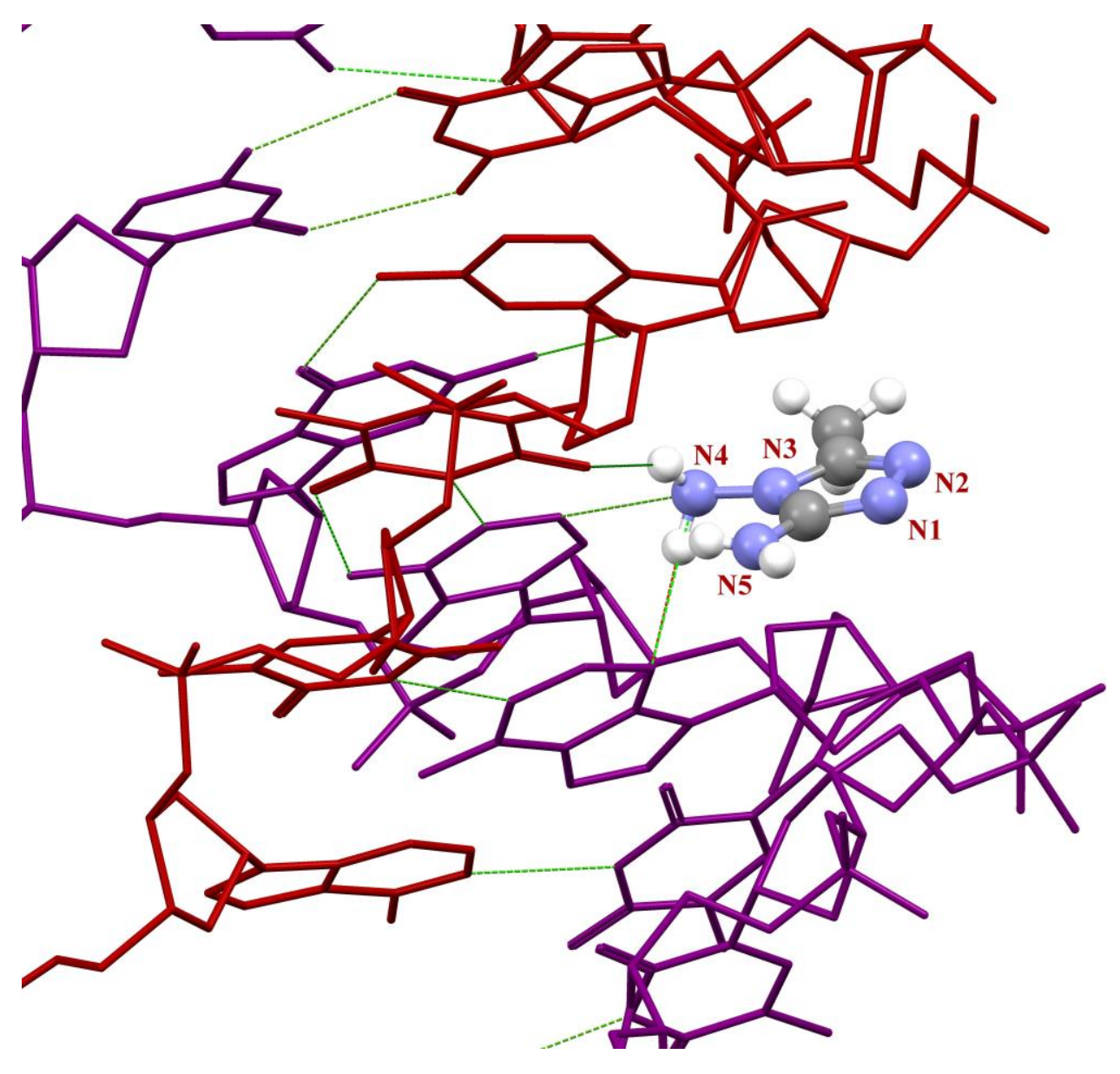

Figure 4. 


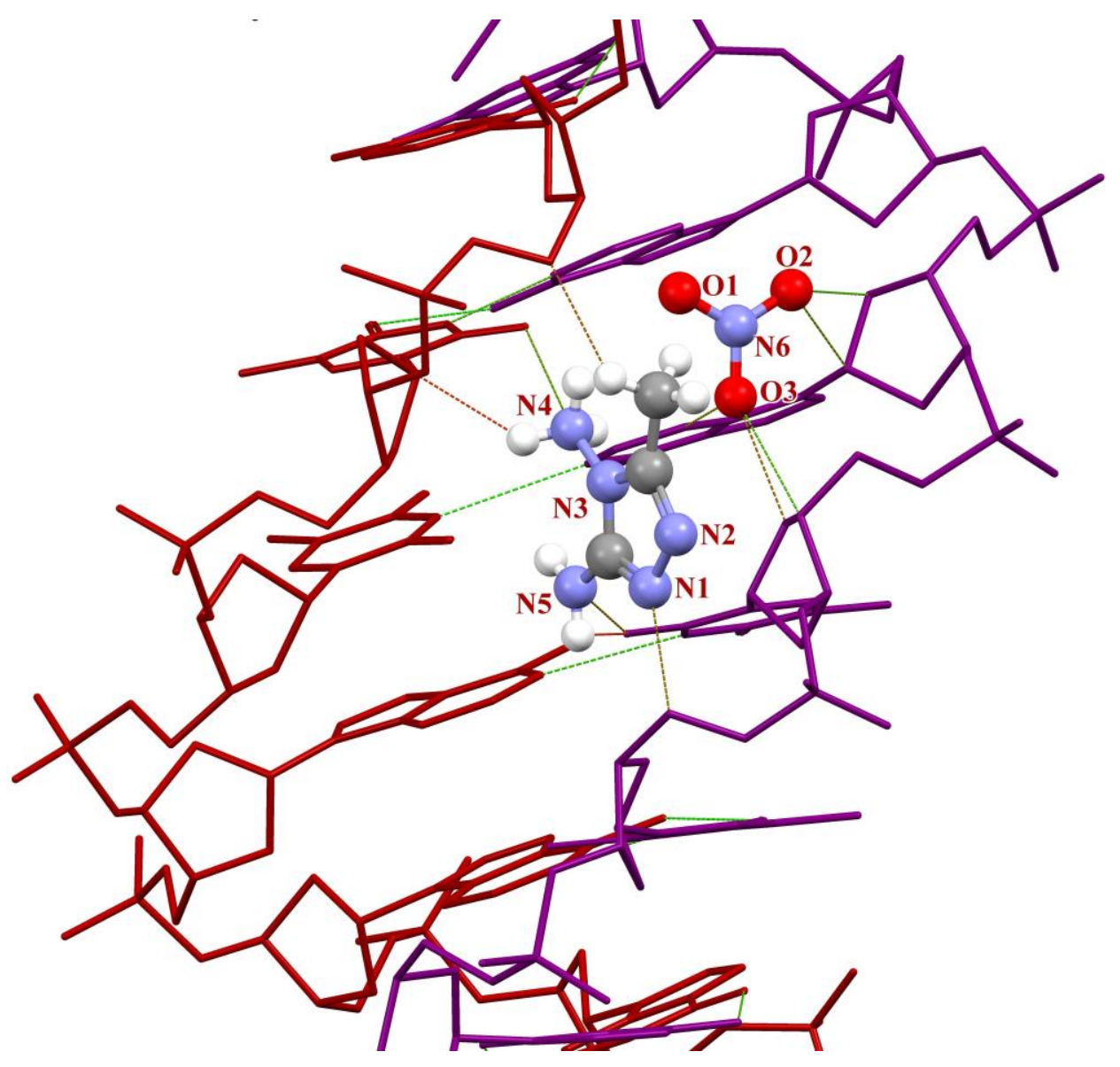

Figure 5. 


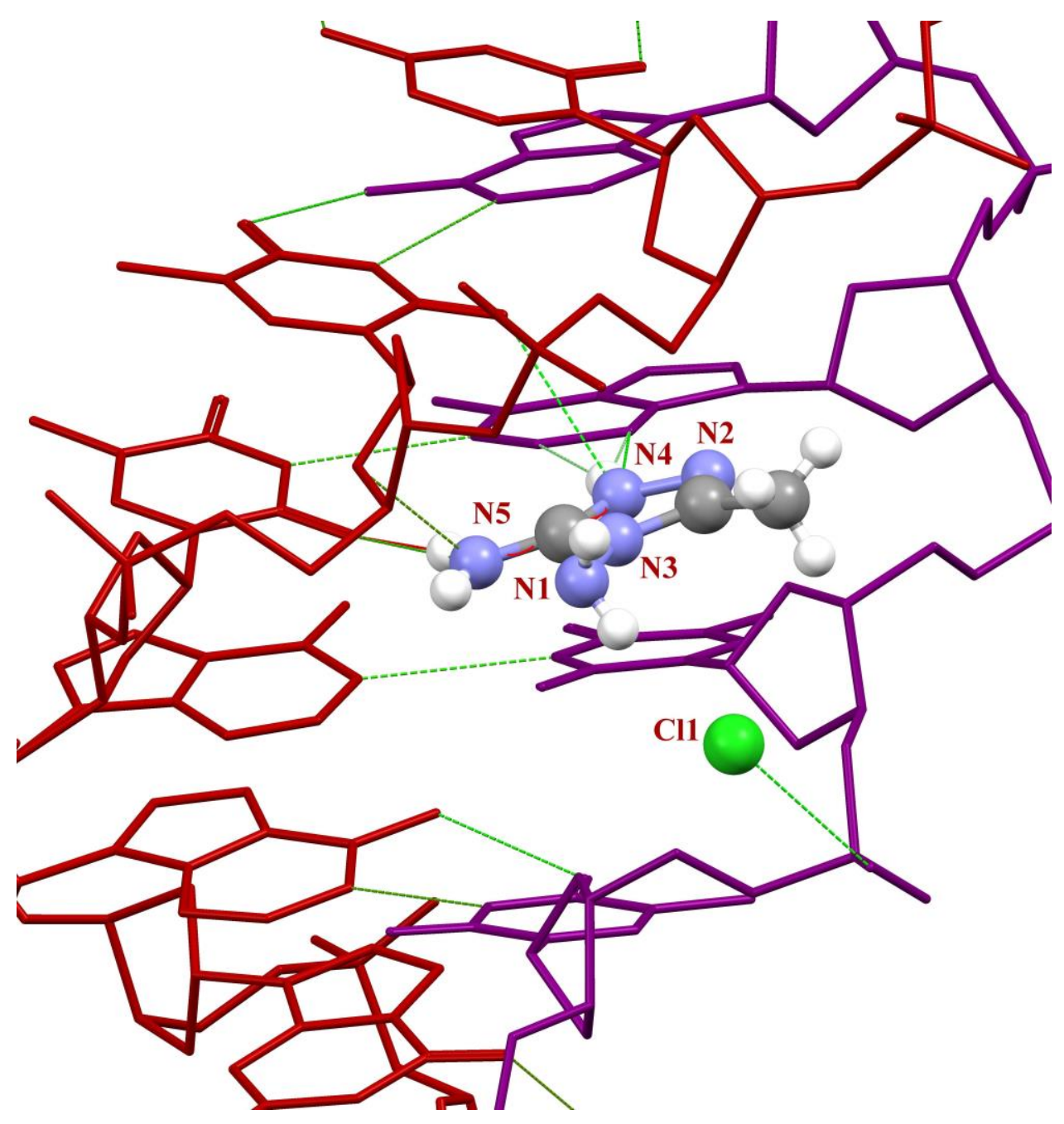

Figure 6. 